\title{
Post-Pandemic National Economic Recovery:
}

\author{
SMEs as the key of success
}

\author{
Karnida Retta Ginting*, Galuh Pancawati \\ Polytechnic STIA LAN Jakarta, National Institute of Public Administration (NIPA) \\ Jakarta, Indonesia \\ *Retta.ginting@gmail.com, Galuhpancawati@gmail.com
}

\begin{abstract}
The existence of SMEs is vital in the Indonesian economy, it is recorded that the number of SMEs has reached 64.19 million units or $99 \%$ of the total business units in Indonesia. SMEs employ more than 116 million workers or $97 \%$ of the total workforce in the economic sector. SMEs contributed $60.34 \%$ of the total national GDP, $\mathbf{1 4 . 1 7 \%}$ of total exports and $58.18 \%$ of total investment. The Covid-19 pandemic has an impact on the national economy including the existence of SMEs. The data shows that $82.9 \%$ of SMEs were affected by the Covid19 Pandemic, seen from the decrease in the number of sales of MSME products. The government realizes that the existence of SMEs must be fought for. The economic recovery policy is a solution offered by the government, which is realized through PEN (National Economic Recovery). SMEs economic policy through PEN is seen from four aspects, communication, resources, disposition, and bureaucracy. The results showed that the PEN policy had an impact on improving the economy of SMEs. This can be seen from the number of recipients of the KUR (People's Business Credit) subsidy of 5 million customers. Communication indicators play a significant role in the successful implementation of PEN. the obstacles are related to red tape bureaucracy, such as a rigidness and being not flexible, anda too many administrative procedure.
\end{abstract}

Keywords—pandemic, SMEs, economic policy

\section{INTRODUCTION}

Corona Virus Disease 2019 (Covid-19), which initially spread in Wuhan China at the end of 2019 has finally spread globally. In March 2020, the World Health Organization (WHO) declared Covid-19 as global pandemic. Pandemic conditions have an impact on all sectors of public life. From a health perspective, the spread of the virus is widespread and the number infected with the virus is increasing, which can be seen from the following graphite:

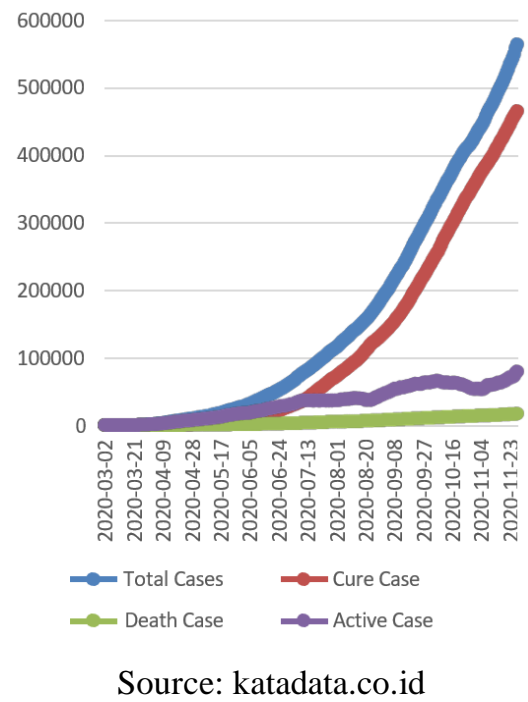

Fig. 1. The spread of the virus

Indonesian government responded by issuing a policy in PP No.21/2020 concerning Large-Scale Social Restrictions (PSBB) in the Context of Accelerating the Handling of Corona Virus Disease 2019 (Covid-I9) [1], with the aim of limiting the movement of the community so that it can suppress the spread of the Covid-19 virus. The policy undertaken by the government to prevent the spread of this virus from spreading is through the PSBB. Of course, this policy has a significant impact on the growth of the economic sector.

The community must follow the PSSB policies taken by the government, so that economic activity is hampered. PSBB and working from home (WFH) policy have reduced economic activity due to restrictions on space for movement which have resulted in a decrease in the level of income and purchasing power of people. There was a decline in economic growth for two consecutive quarters, namely minus 5.32 percent in the second quarter and minus 3.49 percent in the third quarter of 2020. This data illustrates that Indonesia is entering a recession.

Pandemic that has an impact on the economic sector also has an impact on the SMEs sector [2]. The decline in the income of the SMEs sector is one of the causes of the decline 
in economic growth. The decline in economic growth can be assessed from the gross domestic product (GDP). The GDP component is household consumption. Pandemic conditions have caused people's purchasing power to decline, which has a major impact on economic growth.

SMEs contribute $60 \%$ of the total Gross Domestic Product (GDP) or around IDR 8,400 trillion. SMEs are able to absorb $97.02 \%$ of the total workforce and $99 \%$ of the total employment, besides that, SMEs investment provides an investment value of $58.18 \%$ of the total investment.

Regarding the economic downturn, the government made policies that were contained in PP No.23/2020 [3] concerning the Implementation of the National Economic Recovery Program in Support of State Financial Policy for Handling the Covid-19 Pandemic and / or Facing Threats That Endanger the National Economy and / or Financial System Stability and National Economic Rescue, The government has prepared a stimulus through the National Economic Recovery (PEN) program. This form of stimulus includes preparing interest subsidies for credit, exemption from Article 25 Final Income Tax (PPh) for 6 (six) months in the tax policy PMK 44/PMK.03/2020 concerning Tax Incentives for Taxpayers Affected by the Covid-19 Pandemic, starting March 2020 and the Allocation of State Investment (PMN) to BUMN for SMEs.

Entering the new normal period, the policies taken by the government need to be reviewed in order to obtain results on how the implementation has been carried out against the policies taken and what obstacles are faced. This paper is interesting and important to study to see how the PEN policy was implemented and the problems it experienced.

\section{LITERATURE REVIEW}

\section{A. Public Policy}

The pandemic has an impact on all sectors, especially the economic sector. This situation has become a public problem and has a high level of urgency. This can be seen from how the government responds to this problem. Economic issues related to the decline in the productivity of SMEs have entered the government's agenda. Through PEN, the government provides its intervention so that it is hoped that the stretching of SMEs will increase again. In this journal, researchers will see how the implementation of PEN by using the concept of policy implementation from Edward III which sees the success and failure of a public policy from four aspects, namely communication, resources, disposition, and bureaucracy.

The first aspect is communication. Communication, simply defined as the transmission or constitution of a message between two or more people, involves a number of factors: sender; message; channel; receiver; perception; and feedback. [4]. However, interpreting communication in public policy cannot be that simple. Communication is the object of policy, as witnessed in the efforts by government and nongovernment agencies to inform and educate various publics about problems in society. [5] communication plays an important role in public policy and has a wide impact. How a message in policy is conveyed to the public is one of the determinants of policy success. In this paper, the communication aspect seen is one-way communication carried out by the government to the subject of policy-namely SMEs actors. The communication aspect can be seen from how the government delivers its message, the media used, and how to explain existing policies to the public. Communication is essential, in the phenomenological sense, to public policy in a democracy. [5] Good communication skills by the government in conveying matters regarding the resolution of public issues are important to be studied more deeply. When looking at the communication aspect, we actually see other values in it, such as participation and collective awareness.

In many countries, collaboration, awareness, participation and ongoing interaction not only with citizens, but also with business organizations, has become an important attribute of change in governance, particularly in government information policy [6]. Communication can also be seen on how successful the government is in establishing good relations with the community. Of course it is understood that a good policy will not be implemented properly when the government as a policy maker fails to communicate its aims and objectives clearly to the people who are the people who will carry out the policy. Communication is considered to be one of the important variables in achieving the success of a policy.

The second aspect is resources, which is meant by resources in a broad sense, with regard to all kinds of inputs that will affect the processes and outputs of a public policy. Looking at the broader context, resources can be categorized into human resources, material resources, financial resources, and information resources [7]. Public policy implementation certainly cannot run without allocated resources. In this research, the resources to be addressed are organizational resources in accordance

with the concept brought by Edward III. Organizational resources consist of staff, information, authorities, facilities, buildings, equipment, land, and supplies. Staff is defined as employees in the bureaucratic scope, or known as street level bureaucrats. Human resources in a good organization will drive the success of a policy, the competence and capacity of employees are absolute requirements. Policies should be understood by all parts of the organization, not only at the leadership level but must also be properly internalized to the employee level below. Next, is information, namely all information regarding how the policy is implemented and how the compliance of the policy implementer is. Third is the authority or authority related to the legitimacy of the policy implementer in implementing policies, when a policy is legalized, of course the existing resources are part of it, this authority is also in addition to the use of resources, it is also related to how the power possessed by policy implementers in facing the public. The third part of resources is the facilities owned by the organization, both facilities and infrastructure that support policy implementation. 
The third aspect is the disposition or character and characteristics of the implementor, whether he is properly committed to fully implementing a policy. Policy makers and actors if those who have a tendency of traits and attitudes.

The last aspect is the structure of the bureaucracy, the bureaucracy is the most important institution in implementing policies, although not the only one. However, the quality and existence of the bureaucracy will certainly affect the success of policies, because from the very beginning of the emergence of policies to their implementation, the bureaucracy is there. In current governance, it is certainly understood that the implementation of policy implementation cannot only be left to the bureaucracy, but also involves other stakeholders, including the private sector and other non-profit institutions. In reviewing public policy, Edward III offers two variables in the bureaucratic structure, the first is the availability of SOPs related to technical policy implementation, and the second is the fragmentation or ability of bureaucrats to separate themselves from other stakeholders with regard to neutral choices in public policy. These two things are considered quite difficult to do considering that the bureaucracy itself is in the midst of other stakeholders who are equally implementing policies.

\section{B. SMEs}

According to the World Bank, SMEs can be grouped into three types, namely (1) Micro Enterprises (10 employees), (2) Small Businesses (30 employees), and (3) Medium Enterprises (up to 300 employees). From a business perspective, SMEs are classified into four groups, namely: (1) informal sector MSMEs, for example street vendors. (2) Micro SMEs are SMEs with the ability of craftsmen but lack the entrepreneurial spirit to develop their business. (3) Dynamic Small Business is a group of SMEs capable of entrepreneurship by establishing cooperation (accepting sub-contract jobs) and exports and (4) Fast Moving Enterprise is a UMKM that has competent entrepreneurship and is ready to transform into a large business.

Based on data from the Ministry of Cooperatives and Small and Medium Enterprises (KUKM) and the Central Statistics Agency (BPS), every year the number of SMEs is getting bigger. The following is an illustration of the growth in the number of SMEs and the contribution of SMEs to Indonesia's GDP.

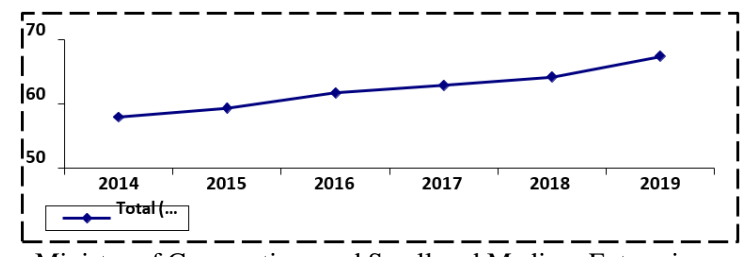

Source: Ministry of Cooperatives and Small and Medium Enterprises.

Fig. 2. Growth of MSMEs
Seen from the growth rate of SMEs, it was added that the contribution of MSMEs to Gross Domestic Product (GDP) also experienced an increase in growth. It can be seen in the following graph:

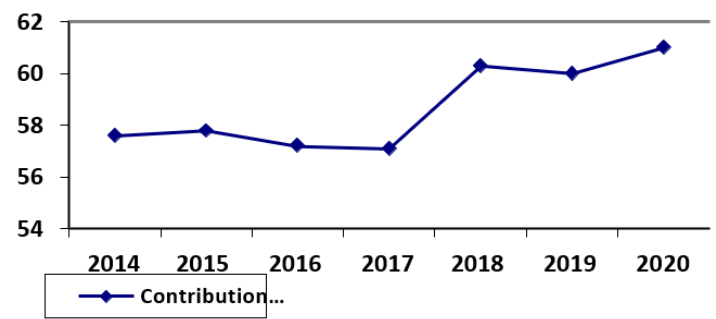

Source: Ministry of Cooperatives and Small and Medium Enterprises.

Fig. 3. Contribution of SMEs to Gross Domestic Product (GDP).

\section{The impact of Covid on SMEs}

The government's large-scale social restrictions (PSBB) and work from home (WFH) policies have an impact on reducing economic activity. From the demand side, there has been a drastic decrease in the number of consumers due to the disrupted economic conditions of the community and they prefer to stay at home. Meanwhile, from the supply side, there was a decline in the production of SMEs products due to the limited number of workers due to PSBB, limited raw materials and increased prices, and difficulties in product distribution.

SMEs players need government policy support to be able to deal with pandemic conditions. Research by Yi Lu et.al. [2] states that small and medium enterprises need financial support from the government, tax subsidies, financial support, employment subsidies, and operational subsidies. Access to external financing can mitigate the risk of cash flow disruption, reduce financial costs, reduce loan interest rates in order to support the economic recovery period.

\section{METHODS}

The research method uses a literature review study starting with selecting scientific journals that are in accordance with the research theme, namely economic policy during the pandemic. The various existing sources are then sorted and evaluated. The author looks at trends and what similarities exist in the existing journals and writings and then processes them. Apart from indexed journals, the author also uses other sources in the form of books, magazines, potpourri, and other literature. The selected publication is the latest publication in 2020 which focuses on improving the economy of MSMEs. The keywords used are SMEs, Covid-19, economy, and policy analysis so that they are relevant to the current analysis. PEN policy analysis is seen from four variables, namely communication, disposition, bureaucracy, and resources.

\section{DISCUSSION}

The policies taken by the government to encourage economic growth in general and especially for SMEs need to 
be studied, whether the policies and implementation carried out have a direct impact on SMEs. To see the PEN policy, this paper will look at four policy variables.

\section{A. Communication}

Communication in PEN research can be seen from three indicators. The first indicator is the transmission or transmission of communication. Transmission is carried out through various media both online and offline. This policy is considered successful when the information submitted can be accepted and understood by the target group, in this case the SMEs actors. The communication channel used by the government through online media is to use the website www.covid19.go.id as the official government website. In addition, the government collaborates with private media such as Kompas, Media Indonesia, Kontan, katadata, and also government public relations under the relevant technical ministries.

Through this channel the government communicates to the wider community regarding how PEN implementation is carried out, including with regard to updating information related to PEN. In these channels it is also hoped that the community will become close to the PEN policy. Another benefit that can be obtained when this policy is disseminated to the public on an ongoing basis is also the emergence of more widespread transparency, the public can become policy observers, so that this PEN policy is implemented properly and of course the previously set goals can be achieved.

The second indicator is clarity regarding the message conveyed. This second indicator cannot be separated from the first indicator, if the channels used by the government are good, it will certainly be more effective if what is conveyed through these channels is relevant, up to date information, and of course the clarity of the substance of the information. The success of this indicator can be seen from the increasing number of target groups that have proposed financing. One of the reasons for this increase is that there is consistent and clear information to implement or implement. Pervasive data can be seen from the following graph:

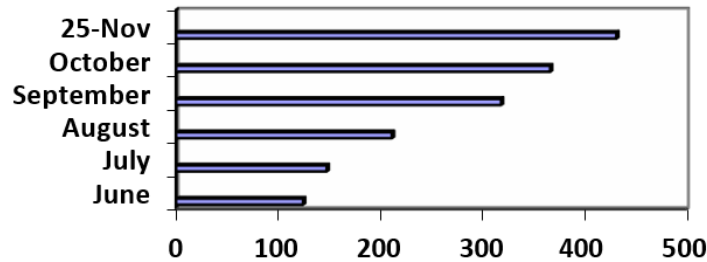

Source: Ministry of Finance, processed data.

Fig. 4. PEN budget absorption data.

The third variable is consistency with regard to the information submitted by the government. The substance conveyed through the existing channels, apart from clarity, also relates to consistency. The manifestation of the consistency variable in the communication carried out by the government in the PEN policy is information related to the requirements and methods of registration for submitting the Presidential Assistance for Productive Micro-SME Enterprises. This clarity and consistency shows that in planning PEN policy, the government has made thorough preparations. Keep in mind that this requirement is also part of the completeness of administration, where it is still an important part of the current bureaucracy.

\section{B. Resource}

Organizational resources consist of staff, information, authorities, facilities, buildings, equipment, land, and supplies The first resource is staff, which are then referred to as street level bureaucrats or all employees in ministries and institutions who are concerned with the implementation of PEN policies. Human resources in the organization certainly influence how policies are implemented. One of the competency and capacity analysis of street level bureaucrats can be seen from the services provided with regard to information about PEN. The public relations staff of the Covid Task Force are responsive to community questions and complaints. This can be proven by the existence of community services provided by the task force, as well as the relevant ministries to answer questions and complaints by the public. The next resource is information, what is meant by information here is all information that can be useful for the success of PEN, including information on the number of SMEs, information relating to the budget provided, the forms of existing stimulus, to policies that are the basis for implementation. PEN. This information is used as the basis for policy implementation. Furthermore, the Covid Task Force also has real authority with regard to the implementation of PEN before all relevant ministries and agencies. They have the authority to regulate how the policy is implemented. The extent of authority can also be assessed from the urgency of policy in the eyes of the government. The resources allocated in relation to PEN are not insignificant. The next resource is seen from the budget provided. The government takes the PEN policy with the following details:

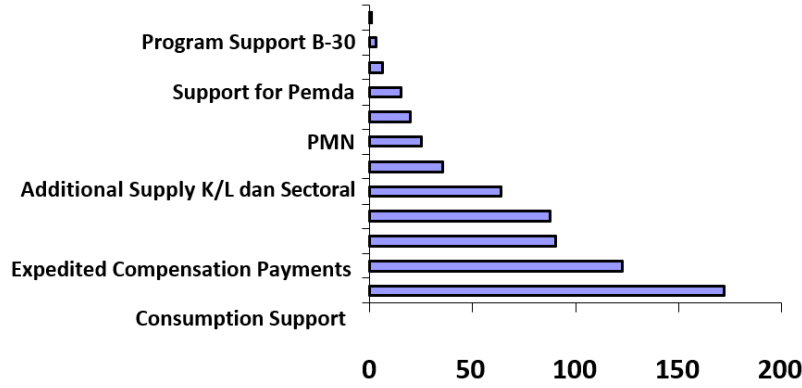

Fig. 5. The government takes the PEN policy.

Especially for SMEs, the Government prepares a budget for saving SMEs reaching IDR 123.46 trillion with details: 


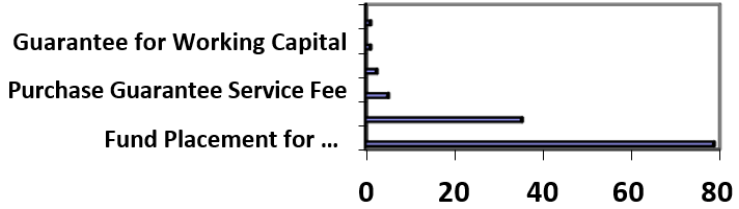

Fig. 6. The Government prepares a budget for saving SMEs.

\section{Bureaucracy}

The last variable is related to bureaucracy. It can be said that this variable is the key to PEN implementation. Analysis related to the bureaucratic structure, namely all matters relating to how the entire bureaucracy runs PEN. More specifically, the quality of the bureaucratic structure is seen from the availability of SOPs and the ability of fragmentation. With regard to SOPs, PEN implementation has been complemented by existing SOPs. However, what has become the finding is that the uniqueness of the bureaucracy to date is related to its rigid nature. This rigidity has become a new problem because the government (bureaucracy) is considered unable to be flexible in dealing with problems in the field. He added, in an emergency situation such as the current pandemic, of course, high flexibility is needed in handling public problems, and currently the government is considered to have failed to implement it. Everything that is done by the bureaucracy must be based on the existing SOP, although the SOP also does not always cover problems encountered in the field. Indef's findings reveal that what is an obstacle in the absorption of PEN funds is that the funds that have been budgeted for national economic recovery still have to be included in the relevant technical departments, which need a process to enter the technical department budget implementation checklist (DIPA).

Another obstacle is that in abnormal conditions that occur there are no instructions for cutting the bureaucracy, so submitting a PEN budget is the same as when submitting a technical budget, which ultimately slows down PEN funds to the public.

\section{Another Finding}

The success of the PEN policy will certainly be influenced by the four variables above. However, policies must also be supported by changes in the strategies of MSME players who follow changes by utilizing technology. There are several recommended survival strategies that SMEs can do to be able to maintain their business, namely (1) the use of technology through e-commerce and social media. E- commerce, which is considered to be a way out for SMEs, in the current pandemic, when social restrictions are imposed, the UMKM that can survive are businesses that use technology. Because with the use of technology, social distancing policies can be fulfilled and on the other hand the business can still run. It can also be seen that online shopping is becoming a new trend nowadays. Social media is also used as a means of marketing for SMEs products, so that it can be seen by consumers more broadly. (2) quality improvement, SMEs actors must improve the quality of their products or services to be able to compete and attract consumers. Increasing the quality and quality of products will have an impact on creating consumer trust and fostering customer loyalty.

\section{CONCLUSION}

From the results of the above discussion, it can be concluded that the implementation of the PEN policy has a good impact on economic recovery after the pandemic. To revive the national economy after experiencing a recession, it is important to revive SMEs because SMEs play a direct role in the people's economy. In order for PEN to be more absorbed, there is a need for discretion in the expenditure of the PEN budget because the budget used is not a routine government budget. The biggest task of the house is to jointly oversee the PEN policy to run as planned, but also must be responsive to pay attention to unexpected needs that then arise in the field. The government must be adaptive and responsive in solving these problems.

\section{REFERENCES}

[1] PP No.21/2020 tentang Pembatasan Sosial Berskala Besar Dalam Rangka Percepatan Penanganan Corona Wrus Disease 2019 (Covid-I9)

[2] Y. Lu, J. Wu, J. Peng \& L. Lu, The perceived impact of the Covid-19 epidemic: evidence from a sample of 4807 SMEs in Sichuan Province, China, "Environmental Hazards", 19(4): 323-340. 2020.

[3] PP No. 23 Tahun 2020 tentang Pelaksanaan Program Pemulihan Ekonomi Nasional Dalam Rangka Mendukung Kebijakan Keuangan Negara Untuk Penanganan Pandemi Corona Virus Disease 2019 (Covid- 19) Dan/Atau Menghadapi Ancaman Yang Membahayakan Perekonomian Nasional Dan/Atau Stabilitas Sistem Keuangan Serta Penyelamatan Ekonomi Nasional.

[4] J. Longo, Communication in the Policy Process. White Paper Oak Bay Avenue.info@ebriefings.ca. 2017.

[5] E.E. Peterson, An Introduction to Communication and Public Policy. Communication and Public Policy, "Proceedings of the 2008 International Colloquium on Communication". 2008.

[6] A. Sanina, A. Balashov, M. Rubtcova, and D.M. Satinsky, The effectiveness of communication channels in government and business communication. "Information Polity", 22(4), pp.251-266. 2017.

[7] S. Hodge, W. Arthur, and P. Mitchell, Effects of temporal priority on interspecific interactions and community development. Oikos, pp.350358. 1996. 